\title{
Pichia scutulata, a New Species from Tree Exudates
}

\author{
H. J. PHAFF, M. W. MILLER, AND MARY MIRANDA \\ Department of Food Science and Technology, University of California, Davis, California 95616
}

\begin{abstract}
A novel representative of the yeast genus Pichia has been recovered 11 times during 1968, 1971, and 1972. We regard this organism as belonging to a new species, Pichia scutulata, with two varieties: P. scutulata var. scutulata, the type variety; and $P$. scutulata var. exigua. Strains of both varieties were found in tree exudates but were geographically separated. $P$. scutulata var. scutulata was isolated from slime exudates and flux-wetted soil of Myoporum trees on the island of Hawaii (six strains), whereas P. scutulata var. exigua was found in fluxes or insect borings of various trees in the state of Washington, and in the province of British Columbia, Canada (five strains). P. scutulata var. exigua differs from $P$. scutulata var. scutulata by its slower fermentation rate, weak ability to utilize glycerol, and higher maximum temperature for growth. The type strain of $P$. scutulata var. scutulata is UCD-FST 71-102 (= ATCC $32651=$ CBS 6644), and that of $P$. scutulata var. exigua is UCD-FST 68-979B1 (= ATCC $24185=$ CBS 6836).
\end{abstract}

During an extensive survey of yeasts associated with trees, Phaff et al. (7) isolated six strains of yeast, which they discussed either in relation to Pichia terricola as a variety or as a possible new species. Five strains came from tree exudates or insect borings (frass) in trees from the North American Pacific Northwest, and one strain came from the flux of a Myoporum tree on the island of Hawaii. Subsequent isolations from Hawaii yielded additional strains of this yeast. All strains grew well in a vitamin-free medium and formed four spheroidal spores, which were not dehisced from the ascus when mature. However, the strains differed in the vigor of glucose fermentation: those from Hawaii had a rather strong fermentation, whereas the strains from the Pacific Northwest were latent and slow in fermenting glucose.

In the Kreger-van Rij key to the species of Pichia (2), the properties of the new isolates led to a group of three yeasts: $P$. terricola, $P$. $k u$ driavzevii, and $P$. membranaefaciens. These three species are differentiated by their vigor of glucose fermentation and vitamin requirements. $P$. terricola is vitamin dependent, $P$. kudriavzevii is independent, and $P$. membranaefaciens is variable in this respect. On the basis of glucose fermentation rate, the Pacific Northwest strains showed some resemblance to either $P$. terricola or $P$. membranaefaciens, whereas the Hawaiian strains fermented glucose at about the same rate as $P$. kudriavzevii.

Conclusive proof that the strains from tree exudates represent a new species was obtained from the base compositions of their deoxyribonucleic acids (DNA), which were significantly lower than those of the other three species. The new species is named Pichia scutulata after the frequent occurrence of the four spheroidal spores in a diamond-shaped, planar arrangement (L. adj. scutulatus diamond-shaped). Since the Hawaiian and the Pacific Northwest strains differed in a number of phenotypic properties, two varieties will be described, $P$. scutulata var. scutulata for the Hawaiian strains and $P$. scutulata var. exigua for the Pacific Northwest strains. The latter variety is named after the latent and slow fermentation of glucose (L. adj. exiguus of low intensity or weak).

\section{MATERIALS AND METHODS}

Yeast strains. Samples were collected from trees in British Columbia and the state of Washington in 1968 (7) and from trees on the island of Hawaii in 1971 and 1972. The tree exudates or insect borings were usually streaked directly (one loopful per plate) or, if desiccated, after about $1 \mathrm{~g}$ of material was soaked in $3 \mathrm{ml}$ of sterile water. Streaking was done (on the day of collection) on acidified maltextract agar ( $5 \%$ Fleishmann Diamalt plus $0.7 \mathrm{ml}$ of $1 \mathrm{~N} \mathrm{HCl}$ added per $100 \mathrm{ml}$ of medium after autoclaving, pH 3.7 to 3.8 ). The plates were placed at 20 to $25^{\circ} \mathrm{C}$ until colonies developed (3 to 6 days), at which time counts of distinct morphological colony types were made. Each type was purified by restreaking on $5 \%$ malt-extract agar. All isolates reported in this paper were obtained from different trees or soils (Table 1).

Methods. The characteristics of the isolates were determined by standard methods currently employed in yeast taxonomy (12). DNA extraction and purification were done by a combination of the procedures of Marmur (4) and Bernardi et al. (1). The guanine plus cytosine $(\mathrm{G}+\mathrm{C})$ content of the DNA 
TABLE 1. Isolation data of Pichia scutulata

\begin{tabular}{|c|c|c|c|c|}
\hline Strain no. & Source & Locality & $\begin{array}{l}\text { Percent } \\
\text { of popu- } \\
\text { lation" }\end{array}$ & $\begin{array}{l}\text { Isolation } \\
\text { date }\end{array}$ \\
\hline \multicolumn{5}{|c|}{$\begin{array}{l}\text { Pichia scutulata var. } \\
\text { scutulata }\end{array}$} \\
\hline 71-102 & Slime flux of Myoporum sandwicense & Island of Hawaii & $-b$ & 1971 \\
\hline $71-103$ & Slime flux of $M$. sandwicense & Island of Hawaii & - & 1971 \\
\hline $71-145$ & Slime flux of $M$. sandwicense & Island of Hawaii & 100 & 1971 \\
\hline $71-180$ & Wet soil under Myoporum flux & Island of Hawaii & - & 1971 \\
\hline $72-135$ & Slime flux of $M$. sandwicense & Island of Hawaii & 4 & 1972 \\
\hline $72-147$ & Slime flux of $M$. sandwicense & Island of Hawaii & 100 & 1972 \\
\hline \multicolumn{5}{|c|}{$\begin{array}{l}\text { Pichia scutulata var. } \\
\text { exigua }\end{array}$} \\
\hline $68-914 \mathrm{~B}$ & Slime flux of Populus trichocarpa & Near Lillocet, British Columbia & 10 & 1968 \\
\hline $68-917 \mathrm{C}$ & Slime flux of Acer sp. & Emory Creek, British Columbia & 10 & 1968 \\
\hline $68-930$ & Slime flux of Salix sp. & Near Agassiz, British Columbia & 100 & 1968 \\
\hline $68-931 \mathrm{~A}$ & Slime flux of Salix sp. & Near Agassiz, British Columbia & 100 & 1968 \\
\hline $68-979 \mathrm{~B} 1$ & Insect boring in Picea sitchensis & $\begin{array}{l}\text { Beach section, Olympic National } \\
\text { Park, Washington }\end{array}$ & 30 & 1968 \\
\hline
\end{tabular}

"The percentage of the yeast from each source represents the estimated frequency of its colonies on the isolation plate.

${ }^{b}$ Not determined.

was calculated from buoyant density values in cesium chloride $(8,10)$ and was based on four separate determinations. Micrococcus lysodeikticus DNA, with a buoyant density of $1.7311 \mathrm{~g} / \mathrm{cm}^{3}$, was used as a reference. The buoyant density of the $M$. lysodeikticus DNA was derived from comparison with Escherichia coli K-12 DNA, the buoyant density of which was taken to be $1.7100 \mathrm{~g} / \mathrm{cm}^{3}$. Scanning electron micrography was by the method of Talens et al. (11).

\section{RESULTS}

\section{Latin diagnosis}

Pichia scutulata sp. n.

Pichia scutulata var. scutulata var. n.

In extracto malti cellulae ovoideae, interdum longovoideae, (2.6-6.6) $\times(3.9-11.8) \mu \mathrm{m}$, singulae, binae, aut in catenis brevis, sedimentum, annulus et pellicula tenuis aut crispulata, nonnitida formantur.

Cultura in agaro malti post unum mensem $\left(18^{\circ} \mathrm{C}\right)$ cremea, mollis, nitida et glabra aut farinacea; prope plana; margine glabro et undulato.

In agaro farinae Zea maïs post dies 10 pseudomycelium nullum; interdum paucae cellulae oblongae formantur.

Species heterothallica, diploidea. Asci inconjugati fiunt, habentes 4 sporos spheroideos; asci non rumpuntur.

Fermentatio glucosi solius.

Glucosum, ethanolum, glycerolum, DL-acidum lacticum et acidum succinicum assimilantur at non galactosum, L-sorbosum, maltosum, saccharum, cellobiosum, trehalosum, lactosum, melibiosum, raffinosum, melezitosum, inulinum, amylum solubile, D-xylosum, L-arabinosum, D-arabinosum, D-ribosum, L-rham- nosum, methanolum, iso-erythritolum, ribitolum, galactitolum, $\alpha$-methyl-D-glucosidum, salicinum, glucono- $\delta$-lactonum, 2-ketogluconatum, 5-ketogluconatum, D-glucosaminum, acidum citricum nec inositolum.

Kalium nitricum et kalium nitrosum non assimilantur.

Ad crescentiam vitaminae additae non necessariae sunt.

Crescere non potest in $33^{\circ} \mathrm{C}$.

$\mathrm{G}+\mathrm{C}$ acidi deoxyribonucleati $=32.7 \pm 0.14$ $\mathrm{mol} \%$

Typus: stirps UCD (FST) 71-102 ex Myoporum sandwicence Hawaiiensis isolata est.

In collectione zymotica Centraalbureau voor Schimmelcultures, Delphi Batavorum sub. no. 6644 deposita est.

\section{Pichia scutulata var. exigua var. $\mathrm{n}$.}

Varietas a varietate scutulata differt: fermentatio glucosi lente aut exigue; glycerolum assimilatur exigue; crescere potest in $33^{\circ} \mathrm{C}$ at non potest in $36^{\circ} \mathrm{C}$.

Typus: stirps UCD (FST) 68-979 B1 ex Picea sitchensis Washingtonensis isolata est.

In collectione zymotica Centraalbureau voor Schimmelcultures Delphi Batavorum sub no. 6836 deposita est.

\section{Standard description of Pichia scutulata var. scutulata}

Growth in malt extract: After 3 days at $25^{\circ} \mathrm{C}$, the cells are spheroid to ovoid and occasionally elongate (2.6 to 6.6 ) by $(3.9$ to 11.8$) \mu \mathrm{m}$, single, and in pairs or short chains. An ascending, smooth, thin pellicle, or a slightly wrinkled pellicle, and a ring are present. After 1 month 
there is a sediment, a thin pellicle, and a ring.

Growth on malt agar: After 1 month at $18^{\circ} \mathrm{C}$, streak cultures are whitish to cream colored. The surface is semiglossy and smooth but, in some strains, it is finely granular to rugose. The texture is soft. The cross section is low convex to umbonate or nearly flat. The border is entire with fine lobes to slightly serrate.

Slide culture on corn meal agar: After 7 to 10 days at $25^{\circ} \mathrm{C}$, a rudimentary pseudomycelium may develop consisting of a few branched chains of ovoid to cylindrical cells. Some strains lack the formation of pseudomycelium.

Formation of ascospores: Vegetative cells are heterothallic diploid. Ascospores are formed on most solid media. The spores are spheroidal, and there are usually four per ascus, often arranged in diamond-shaped tetrads. Two of the spores are of mating type a and two are of mating type $\alpha$. The slightly warty spore surface is evident only in a scanning electron microscope (Fig. 1). The spores contain a small lipid globule. The asci do not release the spores upon maturity.

Fermentation: Only glucose is fermented. A full tube of gas is produced in 3 to 4 days.

Assimilation of carbon compounds: Glucose, ethanol, glycerol, DL-lactic acid, and succinic acid are assimilated. The following compounds are not assimilated: D-galactose, L-sorbose, maltose, sucrose, cellobiose, trehalose, lactose, melibiose, raffinose, melezitose, inulin, soluble starch, D-xylose, L-arabinose, D-arabinose, Dribose, L-rhamnose, methanol, iso-erythritol, ribitol, galactitol, D-mannitol, D-glucitol, $\alpha$ methyl-D-glucoside, salicin, glucono- $\delta$-lactone, Ca-2-ketogluconate, K-5-ketogluconate, D-glucosamine, citric acid, and meso-inositol.

Assimilation of nitrogen compounds: Potassium nitrate, -; potassium nitrite, -; ethylamine, +; ammonium sulfate, + .

Growth in vitamin-free medium: Positive.

Growth on $50 \%$ (wt/wt) glucose yeast extract agar: Negative.

Growth in $10 \% \mathrm{NaCl}$ plus $5 \%$ glucose in yeast nitrogen base: Positive.

Maximum temperature for growth: Positive at $30^{\circ} \mathrm{C}$; negative at $33^{\circ} \mathrm{C}$.

Acid formation on chalk agar: Weak or absent.

Hydrolysis of urea: Variable (weak to strong).

Synthesis of starchlike compounds: Negative.

Gelatin liquefaction: Negative.

Casein hydrolysis: Negative.

Lipolytic activity: Negative.

Growth in the presence of $0.1 \mathrm{mg}$ of cycloheximide per ml: Negative.

$\mathrm{G}+\mathrm{C}$ content of the nuclear DNA: $32.7 \pm 0.14$ mol\%.

Habitat: Six strains were recovered during 1971 and 1972 on the island of Hawaii from exudates of Myoporum sandwicense trees and from soil wetted by dripping fluxes (Table 1).

Type: The type strain UCD-FST 71-102, isolated from a frothy slime flux of $M$. sandwicense on the island of Hawaii, has been deposited in the collection of the Yeast Division of the Centraalbureau voor Schimmel cultures in Delft, The Netherlands, as CBS 6644 and in the American Type Culture Collection, Rockville, Md., as ATCC 32651.

\section{Supplementary description of Pichia scutu- lata var. exigua}

Fermentation of glucose: Latent and slow. Usually not more than 50 to $70 \%$ of the inverted vials become filled with gas after 7 to 10 days.

Assimilation of glycerol: Very weak rather than positive.

Maximum temperature for growth: Positive at $33^{\circ} \mathrm{C}$; negative at $36^{\circ} \mathrm{C}$.

Acid formation on chalk agar: Positive.

Hydrolysis of urea: Strongly positive.

Growth in $10 \% \mathrm{NaCl}$ plus $5 \%$ glucose in yeast nitrogen base: Negative.

$\mathrm{G}+\mathrm{C}$ content of the nuclear DNA: $32.5 \pm 0.23$ $\mathrm{mol} \%$.

Habitat: Five strains were recovered from slime fluxes or insect borings in various trees of the Pacific Northwest (Table 1).

Type: The type strain of $P$. scutulata var. exigua, UCD-FST 68-979B1 (Fig. 1), isolated

FIG. 1. Ascospores and asci of Pichia scutulata var. scutulata (a, $c, d$, and $e$ ) and of P. scutulata var. exigua ( $b$ and f) observed by scanning electron microscopy ( $a$ through $d$ ) and by phase-contrast microscopy ( $e$ and f). (a through c) Asci that have been enzymatically digested to remove the ascus wall; ( $d$ ) intact ascus. The spore surface of $P$. scutulata var. scutulata appears to have distinct warts, whereas that of $P$. scutulata var. exigua has a more corrugated surface. The planar tetrad configuration appears to result from incomplete separation of the spores after the process of spore wall formation (a and e). Characteristic lipid globules are distinct in the spores of $P$. scutulata var. scutulata (e). The fact that the lipid inclusions are less distinct in $P$. scutulata var. exigua ( $f$ ) may be related to spore maturity. Note the distended appearance of the ascus wall (d and $e)$ and the swollen appearance of the ascospores, which result in the diamond shape. (a through d) Bar represents $1 \mu \mathrm{m}(\times 10,000)$; (e and f) bar represents $2 \mu \mathrm{m}(\times 5,000)$. 

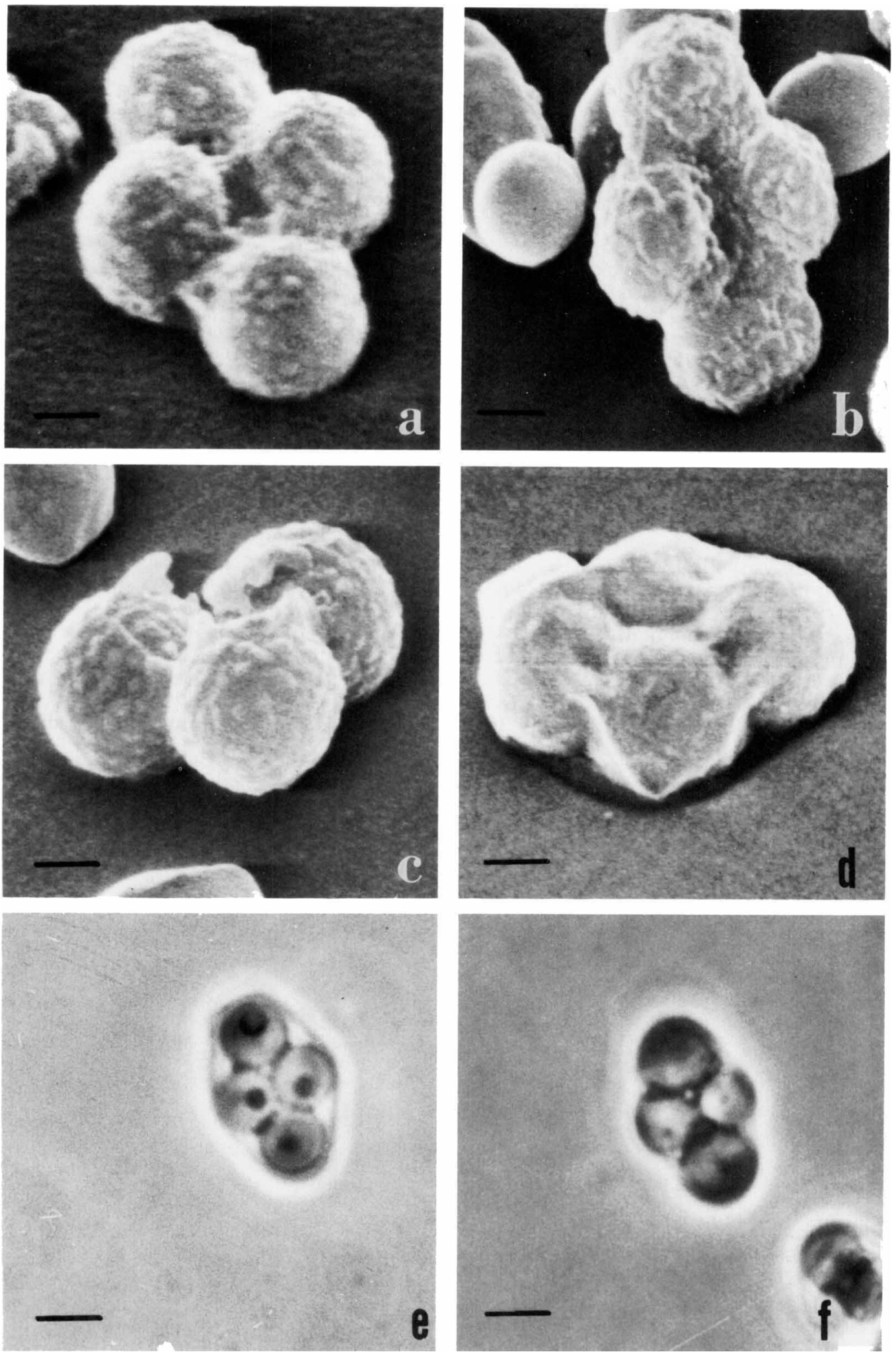

Fig. 1 
from insect borings in Picea sitchensis, Olympic National Park, Wash., has been deposited in the collection of the Yeast Division of the Centraalbureau voor Schimmelcultures in Delft, The Netherlands as CBS 6836 and in the American Type Culture Collection, Rockville, Md., as ATCC 24185.

\section{DISCUSSION}

Although Pichia scutulata bears some resemblance to $P$. terricola, $P$. kudriavzevii, and $P$. membranaefaciens, the values obtained for the DNA base composition of the four species (Table 2) are distinctly different, and P. scutulata therefore represents an independent species. Our $\mathrm{G}+\mathrm{C}$ values, determined by buoyant density equilibrium centrifugation in $\mathrm{CsCl}$, are generally higher than values given in the literature, based on the melting technique $(5,6)$ but, no matter which data are used, the differences between the four species are clear-cut. Since the assimilatory properties of the four species are virtually the same, the most convenient phenotypic properties used to differentiate $P$. scutulata from the others are as follows. $P$. scutulata differs from $P$. terricola by its growth in vitamin-free medium and by its four-spored asci (those of $P$. terricola nearly always contain two spores and only rarely four). It differs from $P$. kudriavzevii by its much lower maximum temperature for growth (lower than $36^{\circ} \mathrm{C}$, versus 43 to $44^{\circ} \mathrm{C}$ ), its fourspored asci, and by its inability to assimilate Dglucosamine. The phenotypic properties available to differentiate $P$. scutulata from $P$. membranaefaciens are the latter's very weak, or lack of, glucose fermentation and its inability to hydrolyze urea. It should also be noted that the spores of $P$. scutulata are not released from the ascus but that they are easily liberated by nearly all strains of $P$. membranaefaciens. Moreover, most $P$. membranaefaciens strains form hat-shaped rather than spheroidal spores. Mating types of $P$. scutulata do not mate with the mating types of either $P$. terricola or $P$. kudriavzevii (C. P. Kurtzman, personal communication). The wartlike spore wall ornamentation of $P$. scutulata (Fig. 1) is quite similar to that of $P$. terricola and of $P$. kudriavzevii (3). Although Kreger-van $\mathrm{Rij}(2)$ reported that $P$. terricola strains grew at $37^{\circ} \mathrm{C}$, we found this property variable for the strains included in this study (Table 2). P. scutulata cannot, therefore, be differentiated from $P$. terricola by maximum temperature of growth.

The Hawaiian strains differed in a number of relatively minor properties from the Pacific Northwest strains. This observation induced us to split $P$. scutulata into two varieties: $P$. scutulata var. scutulata, the type variety, for the

TABLE 2. Salient characteristics of several species of Pichia

\begin{tabular}{|c|c|c|c|c|c|c|c|c|c|}
\hline Species and variety & $\begin{array}{l}\text { Strain } \\
\text { no. }\end{array}$ & $\begin{array}{c}G+C \text { content } \\
(\mathrm{mol} \%)\end{array}$ & $\begin{array}{l}\text { Growth } \\
\text { in } \\
\text { vitamin- } \\
\text { free } \\
\text { medium }\end{array}$ & $\begin{array}{c}\text { Growth on } \\
\text { glycerol }\end{array}$ & $\begin{array}{l}\text { Growth } \\
\text { on } \\
\text { glucos- } \\
\text { amine }\end{array}$ & $\begin{array}{l}\text { Maximum } \\
\text { temp for } \\
\text { growth }\end{array}$ & $\begin{array}{c}\text { No. of } \\
\text { spores } \\
\text { per } \\
\text { ascus }\end{array}$ & $\begin{array}{l}\text { Ascus } \\
\text { dehis- } \\
\text { cence }\end{array}$ & $\begin{array}{c}\text { Fermentation } \\
\text { of glucose }\end{array}$ \\
\hline $\begin{array}{l}\text { Pichia scutulata var. } \\
\quad \text { scutulata }\end{array}$ & $\begin{array}{l}71-102^{a} \\
71-145 \\
72.147\end{array}$ & $\begin{array}{l}32.7 \pm 0.14 \\
32.6 \pm 0.36 \\
33.0 \pm 0.18\end{array}$ & $\begin{array}{l}+ \\
+ \\
+\end{array}$ & $\begin{array}{l}+ \\
+ \\
+\end{array}$ & $\begin{array}{l}- \\
-\end{array}$ & $\begin{array}{l}>30 ;<33 \\
>30 ;<33 \\
>30 ;<33\end{array}$ & $\begin{array}{l}4 \\
4 \\
4\end{array}$ & $\begin{array}{l}\text { No } \\
\text { No } \\
\text { No }\end{array}$ & $\begin{array}{l}\text { Strong } \\
\text { Strong } \\
\text { Strong }\end{array}$ \\
\hline $\begin{array}{l}\text { P. scutulata var. exi- } \\
\text { gua }\end{array}$ & $\begin{array}{l}68-917 \mathrm{C} \\
68-979 \mathrm{~B} 1^{n} \\
68-931 \mathrm{~A}\end{array}$ & $\begin{array}{l}32.4 \pm 0.23 \\
32.5 \pm 0.23 \\
32.6 \pm 0.13\end{array}$ & $\begin{array}{l}+ \\
+ \\
+\end{array}$ & $\begin{array}{l}\text { - or weak } \\
\text { - or weak } \\
\text { - or weak }\end{array}$ & $\begin{array}{l}- \\
- \\
-\end{array}$ & $\begin{array}{l}>33 ;<36 \\
>33 ;<36 \\
>33 ;<36\end{array}$ & $\begin{array}{l}4 \\
4 \\
4\end{array}$ & $\begin{array}{l}\text { No } \\
\text { No } \\
\text { No }\end{array}$ & $\begin{array}{l}\text { Latent, slow } \\
\text { Latent, slow } \\
\text { Latent, slow }\end{array}$ \\
\hline $\begin{array}{l}P \text {. terricola van der } \\
\text { Walt }\end{array}$ & $\operatorname{CBS} 2617^{a}$ & $47.4 \pm 0.24^{b}$ & - & + & - & $>33 ;<36$ & 2 & No & Slow \\
\hline P. terricola & $\begin{array}{l}68-145^{\prime \prime} \\
56-107^{\prime \prime}\end{array}$ & $\begin{array}{l}37.3 \pm 0.13 \\
37.2 \pm 0.34\end{array}$ & - & + & - & $\begin{array}{c}37 \\
>33,<36\end{array}$ & $\begin{array}{l}2 \\
2\end{array}$ & $\begin{array}{l}\text { No } \\
\text { No }\end{array}$ & $\begin{array}{l}\text { Slow } \\
\text { Slow }\end{array}$ \\
\hline $\begin{array}{l}\text { P. kudriauzevii Boi- } \\
\text { din, Pignal, and } \\
\text { Besson }\end{array}$ & CBS $5147^{\circ}$ & $40.1 \pm 0.36^{b}$ & + & + & + & $43-44$ & 2 & No & Strong \\
\hline $\begin{array}{l}\text { P. membranaefaciens } \\
\text { Hansen }\end{array}$ & CBS $107^{a}$ & $44.3 \pm 0.44$ & + or - & + or - & - & 37 or lower & 4 & Yes & $\begin{array}{l}\text { Very weak or } \\
\text { negative }\end{array}$ \\
\hline
\end{tabular}

"Type strain.

${ }^{b}$ Data supplied by C. W. Price (manuscript in preparation).

" This strain was isolated in British Honduras, C.A., from soil.

"This strain (= CBS 5376) was isolated in our laboratory from spoiled figs. 
Hawaiian strains; and $P$. scutulata var. exigua for the Pacific Northwest strains (Table 2). Although representative strains of the two varieties have essentially the same DNA base composition, the possibility that they represent different species cannot be excluded. DNA-DNA hybridization experiments should settle this point.

We considered the possibility that $P$. scutulata var. exigua could be identical to species whose names are now included among the numerous synonyms of $P$. membranaefaciens (2). Two strains were obtained from the CBS culture collection: Pichia punctispora (Mélard) Dekker CBS 190, on the basis of its spore wall ornamentation (9); and Pichia membranaefaciens Hansen var. calliphorae (Kloecker) Dekker CBS 189, since it forms four spheroidal to irregularly shaped spores per ascus (9). However, the DNA base composition of CBS 190 was found to be $43.42 \pm 0.54 \mathrm{~mol} \% \mathrm{G}+\mathrm{C}$; that of CBS 189 was found to be $45.60 \pm 0.37 \% \mathrm{G}+\mathrm{C}$. These values are in agreement with the value found for the type strain of $P$. membranaefaciens (Table 2).

\section{ACKNOWLEDGMENTS}

We are greatly indebted to Gayle Fuson and Chester W. Price for determining the DNA base compositions, to Ellen Barker Johnson for technical assistance, and to Marc André Lachance for his help with the Latin diagnoses. We thank C. P. Kurtzman for the isolation of the mating types and for the demonstration of heterothallism in the new species.

This research was supported by Public Health Service grant GM-16307-05 from the National Institute of General Medical Sciences to H. J. Phaff, by grant GF-258 from the National Science Foundation, and by the Japanese Society for the Promotion of Science.

\section{REPRINT REQUESTS}

Address reprint requests to: H. J. Phaff, Department of Food Science and Technology, University of California, Davis, Calif. 95616.

\section{LITERATURE CITED}

1. Bernardi, G., M. Foures, G. Piperno, and P. P. Slonimski. 1970. Mitochondrial DNAs from respiratory-sufficient and cytoplasmic respiratory-deficient mutants of yeast. J. Mol. Biol. 48:23-42.

2. Kreger-van Rij, N. J. W. 1970. Pichia Hansen, p. 453, In J. Lodder (ed.), the yeasts - a taxonomic study. North Holland Publishing Co., Amsterdam.

3. Kurtzman, C. P., and M. J. Smiley. 1974. A taxonomic re-evaluation of the round-spored species of Pichia, p. 231-232. In H. Klaushofer and U. Sleytr (ed.), Proceedings of the Fourth International Symposium on Yeasts, part 1. Hochschülerschaft an der Hochschule für Boden Kulture, Vienna.

4. Marmur, J. 1961. A procedure for the isolation of DNA from microorganisms. J. Mol. Biol. 3:208-218.

5. Nakase, T. 1971. New species of yeasts resembling Candida krusei (Casr.) Berkhout. J. Gen. Appl. Microbiol. 17:383-398.

6. Nakase, T., and K. Komagata. 1970. Significance of DNA base composition in the classification of the yeast genus Pichia. J. Gen. Appl. Microbiol. 16:511521.

7. Phaff, H. J., M. W. Miller, M. Yoneyama, and M. Soneda. 1972. A comparative study of the yeast florae associated with trees on the Japanese islands and on the west coast of North America, p. 759-774. In G. Terui (ed.), Proceedings of the Fourth International Fermentation Symposium Fermentation technology today. Society of Fermentation Technology, Osaka.

8. Schildkraut, C. L., J. Marmur, and P. Doty. 1962. Determination of the base composition of deoxyribonucleic acid from its buoyant density in $\mathrm{CsCl}$. J. Mol. Biol. 4:430-433.

9. Stelling-Dekker, N. M. 1931. Die sporogenen Hefen. Verhandelingen der Koninklijke Akademie van Wetenschappen Te Amsterdam. Afdeeling Natuur Kunde (Tweede Sectie), vol. 28, no. 1. North-Holland Publishing Co., Amsterdam.

10. Szybalski,W. 1968. Use of cesium sulfate for equilibrium density gradient centrifugation, p. 330-360. In L. Grossman and K. Moldave (ed.), Methods in enzymology, vol. 12B. Academic Press Inc., New York.

11. Talens, L. T., M. Miranda, and M. W. Miller. 1973. Electron microscopy of spore formation in Metschnikowia krissii. J. Bacteriol. 114:413-423.

12. van der Walt, J. P. 1970. Criteria and methods used in classification, p. 34-113. In J. Lodder (ed.), The yeasts - a taxonomic study. North Holland Publishing Co., Amsterdam. 